\title{
The role of forensic geology in the illicit precious metals trade
}

\author{
${ }^{1}$ University of Pretoria, Pretoria, South Africa; Officer for Africa, International Union of Geological Sciences, Initiative on Forensic Geology \\ (IUGS-IFG); *Corresponding author, E-mail: roger.dixon@up.ac.za \\ ${ }^{2}$ Independent Consultant: Mineralogy, Roodepoort; Adj. Prof. JKMRC, UQ; Affiliated Assoc. Prof. Geology Dept, UFS; Adj. Prof, Chem \\ Eng. Dept., UCT, South Africa, E-mail: robertschouwstra5@gmail.com
}

(Received: November 7, 2016; Revised accepted: March 7, 2017)

http://dx.doi.org/10.18814/epiiugs/2017/v40i2/017015

The proceeds of the illicit trade in precious metals are used as currency to pay for, for example, other illicit goods and support terrorism. Precious metals are often mined in less developed countries and exported to and refined in more industrialised regions. International cooperation, sophisticated analytical techniques, combined with representative databases make it possible to trace the source of these stolen precious metals with the aim of obtaining successful prosecution of the culprits. In this paper the problem of illicit trade in precious metal-bearing materials and the effects it has on the countries in which the material originates is discussed. Combined with geological knowledge of the origin of the material and knowledge of the beneficiation processes utilized, enables determination of the provenance of unknown materials and whether the suspect material is illicit or not. Recent legislation with regard to international trade and the need to ensure the legality of the material traded is discussed, and some examples of the effectiveness of the forensic investigation of gold and platinum-group metal criminal cases are provided.

\section{The Problem}

Illegal trade in stolen precious metals and diamonds is very profitable due to their high values and established identities as global currencies. With high poverty levels, especially in the less developed countries, which coincidentally have substantial gold reserves, the theft and illegal mining of gold is rife. For the platinum group metals, which have fewer sources and a more complex beneficiation process, theft is mainly of intermediate products in the beneficiation chain, from smelters and refineries. The ultimate beneficiaries of this illegal trade are often well-organised syndicates also involved in a variety of other illegal activities, such as drug and firearm trafficking, with wide-reaching contacts. These organisations present a global threat, and could best be monitored and opposed on an international level.

Established money laundering systems using gold have been found in many European countries, such as Switzerland and Italy, and from there across the world, including the USA, and South and Central America (UNICRI Report, 2016). Reportedly, Uruguay became the leading gold supplier to the USA during 1989 (George, 2007), even though the country had no gold industry, as a scheme for covering up narcotics profits. International terrorist groups also regularly use gold as a bargaining tool. Prior to and during the US attack on Afghanistan, al-Qaeda moved funds out of that country by smuggling gold, diamonds and other precious stones across borders, and then to Dubai, from where the funds were spread across the world, including the USA (Farah, 2002). Due to the general absence of formal banking systems in the Middle East, North Africa and Asia, the informal Hawala system is often used to refund gold deliveries, where money is transferred across large distances by e-mail or telephone calls, and all records are destroyed afterward. These and many other routes exist whereby illegal funds can be legitimised, using precious metals and precious stones, often themselves having been obtained by illegal means.

The illegal mining of gold in the Democratic Republic of the Congo (DRC) generates profits, which are reportedly used to buy arms and fund the civil war (Donovan, 2014). In the DRC, criminals rely on the state's inability to control its territory and borders. It is reported that around 70 per cent of the gold currently being mined in the DRC has been exported illegally (White, 2005), reaching up to 95 per cent in the eastern DRC (BSR, 2010). A large volume of illicitly mined gold is smuggled into Uganda where it is bought by traders who, by completing the requisite customs and export forms, export it legally and in the process launder it (Bariyo et al., 2013). Although Uganda has relatively little domestic gold production, it was still able to export US $\$ 60$ million in gold in 2002. A large proportion of this gold is known to have reached South Africa (Haken, 2011). The thriving illicit gold market in South Africa is also a market for illicit gold from other parts of Africa, including the so-called "blood gold", mined in war-torn regions in order to fund paramilitary activities (Bariyo et al., 2013). In 2012, the Rand Refinery, the largest gold refiner in the world, processed over 440 tons of gold, almost twice the legal production recorded for South Africa. The balance of the gold refined was mainly from South American and African sources, and submitted by a variety of parties (Rand Refinery, 2012).

The illicit gold trade is worth more than US \$2.3 billion annually. Major producers of illicit gold are Peru ( $40 \%$ of its gold production in 2012 was illegal), Russia, Mali, Brazil, Uzbekistan, Papua New Guinea and Argentina. The rise in the price of gold has spurred on the illicit trade, as policing the artisanal producers is often impossible or very difficult (Haken, 2011). Most of the profits go to the middlemen, 
who in many cases are syndicates, and the country of origin benefits little from this illegal trade. As a result of the extent of the illicit mining in Peru, and its damage to the economy, illegal mining has been criminalised and the Peruvian government is making a major effort to curb these activities, after years of inaction (Andean Air Mail and Peruvian Times, 2012).

Compared to gold, world-wide platinum production is relatively small. Platinum supply in 2015 was just less than 200 tonnes (around 6 percent of the total gold production). The complexity of platinum group metal processing and refining means that illegal mining is almost unheard of in the platinum industry. The theft of products is however a much more serious problem. In 2006, the Institute of Security Studies estimated that US\$37 million of platinum group metals were stolen and exported from South Africa in one year through the activities of one syndicate, whereas in 2008 the estimated annual value of stolen material worldwide was 150 million Euros (CIP Project Report, 2008). Mining companies have put extensive security procedures and systems in place to protect the refineries where the highgrade materials are produced. However, this has forced product theft upstream, with smelter products being especially at risk, although the last few years have also seen an increase in theft from concentrators.

The large loss of income to the mining industry as a result of illegal mining, as well as the theft and illicit trade in precious metals, simultaneously results in a loss of national income to the state from revenue, as well as a loss of available jobs to mineworkers as a result of increased production costs. The domino effect of job losses leading to a variety of economic and social problems can have crippling effects on entire communities due to the extremely high rates of unemployment. In South Africa, one worker is estimated to support an average of about 10 people who are dependent on this income (Stoddard, 2013). This problem has echoes in a number of other countries (Haken, 2011).

The circulation of illicit gold and platinum group metals is controlled by large criminal syndicates, which are heavily involved in other criminal activities within South Africa (Coetzee and Horn, 2007). Shipments of precious metals from other countries can readily be assimilated into the illicit gold circuit, and illicit precious metals from South Africa are also shipped to refineries in Europe.

In South Africa there exists a legal requirement to relate recovered stolen precious metals (i.e. natural (alluvial, etc.), stolen from mine, smelter or illegally processed in a backyard) to source, and also to identify the process by which it was beneficiated in order to confirm or refute its origin (Precious Metals Act, 2005; Smith, 2008) (Figure 1).

Section 1502 of America's Dodd-Frank Wall Street Reform and Consumer Protection Act requires companies listed on the US Exchanges dealing with the $3 T^{\prime}$ 's (tin, tungsten and tantalum), gold and also gemstones, to submit an annual report describing their measures to ensure their material is "conflict-free" (Dodd-Frank, 2010). The World Gold Council has implemented procedures that require certification of origin of all gold mined by its members (World Gold Council, 2011). These actions place the onus on each council member to certify the origin of its gold in that it originates from legal and licit sources. A means to cross-check these statements of origin would be to have a database of known gold samples and a methodology to compare those samples with the gold being traded.

The Kimberley Process has been developed to "identify" blood diamonds (United Nations, 2000), but cannot always be implemented

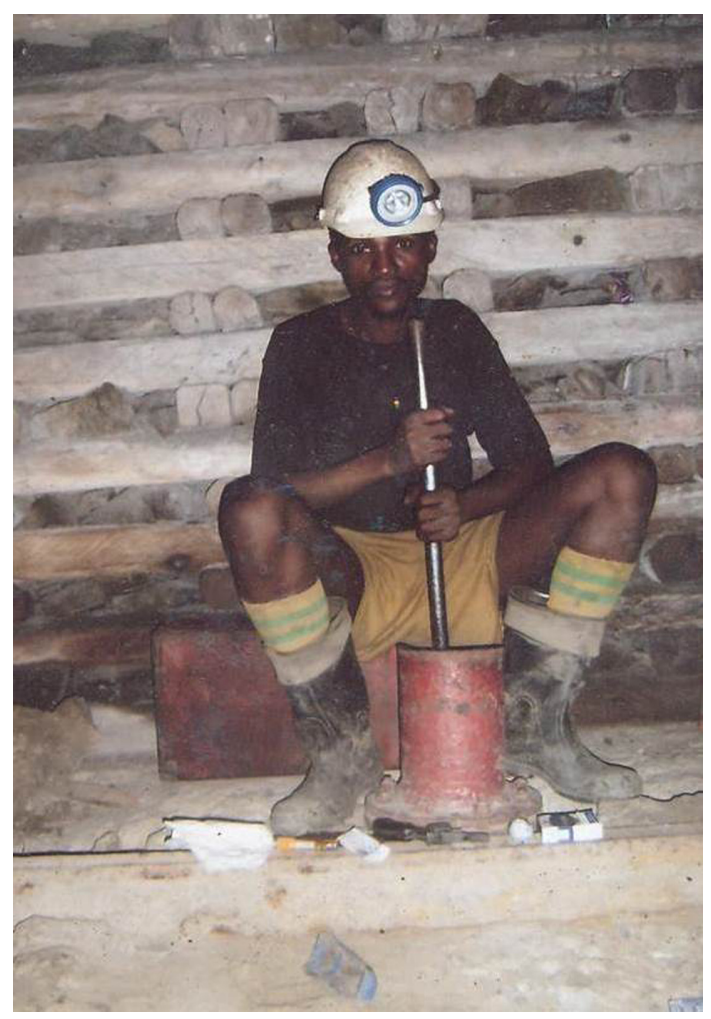

Figure 1. Illegal miner underground, with a mortar and pestle in which concentrate is crushed together with mercury to amalgamate the gold particles. The photograph was retrieved from a camera belonging to an illegal miner (Photo: Willem Els).

successfully. On the opposite end of the spectrum, it is a relatively simple process to implement for "coltan", or columbite - tantalite (e.g. Savu-Krohn et al., 2011; Gäbler et al., 2011), much of which derives from the war-torn areas of Africa (Lublinski et al., 2010). Similarly, due to its nature, it is possible to fingerprint precious metals. Fast identification of illicit precious metals using certified and internationally accepted methods utilising universal databases, and identification of the original producers, would promote worldwide cooperation and trust. It should ultimately be possible to prevent illegally obtained precious metals from re-entering the legal economic systems, and therefore drastically reducing the profits to the smugglers.

\section{Legal and Forensic Requirements}

Smith (2008) looked at international legislation regarding precious metal mining and trade, and showed that there was no consistency in legislation. The legislation in South Africa was considered to be the most comprehensive. The examples presented below are taken from a mainly South African perspective. There is a legal requirement in South Africa to relate recovered stolen precious metal (this includes intermediate materials which are precious metal bearing) to source, in order to confirm or refute its origin (Precious Metals Act, 2005; Smith, 2008). This requirement is needed as part of a criminal case, to prove guilt relating to the possession of unwrought stolen precious metals, as well as determining the legal owner of the precious metals in order to return it to them. 
In a study looking at the burden of proof during litigation in South African courts of law, de la Rey (2007) assessed the differences between "beyond reasonable doubt", required for criminal cases, and "balance of probability" required for civil cases. In South African case law, probabilities must be based on proven facts ( $\mathrm{S} \vee$ Abrahams, 1979) and proof is delivered by means of deductions derived from these facts (Schmidt and Rademeyer, 2006), with the difference between a criminal matter being that the deduction must be the only reasonable deduction, and the deduction in a civil case must be the most probable one. Nowhere in South African nor English law is absolute proof necessary.

Analysis of suspected stolen precious metal for court purposes can be done by a single competent person: "Section 208 of the [Criminal Procedure] Act stipulates that an accused may be convicted on the evidence of a single and competent witness. This does not displace an important principle in our law that the evidence of a single witness must be approached with caution. Before the court can place any reliance thereon, the evidence of a single witness must be clear and satisfactory in every material respect. In other words, the evidence must not only be credible, but must also be reliable." (S v Janse van Rensburg and Another, 2008).

Forensic science is the application of the laws of physics and chemistry to interrogate evidence. In other words, the processes surrounding the piece of evidence that give rise to its appearance and composition, which are properties that can be determined by analysis. In the examination of a piece of suspected precious metal, traditional forensic concepts involved would be identification (classification), association (linking) and reconstruction (understanding the sequence of events). Inman and Rudin (2002) showed that this traditional approach failed, and that the concept of "divisible matter" had to be incorporated, to take into consideration the "origin, change and subsequent relationship of physico-chemical traits in the evidence and reference samples".

In light of the above discussion, it can be seen that for physical evidence that was once part of a whole, and in this case we are considering pieces of precious metal, or precious metal-bearing material, which originated from a specific location or mine, it is necessary to be able to demonstrate a shared origin or source by comparison of the evidence to material from the putative source. This implies that a collection of samples must be available for comparison that would comprise a database. Saks and Koehler (2005) state that "data should be collected on the frequency with which... attribute variations occur in different populations. In addition to their case-specific benefits, these data may also facilitate the development of computer-aided pattern recognition programs...". It is not necessary to prove uniqueness for forming forensic conclusions, nor is it possible in the case of a piece of precious metal coming from a particular source. As Page et al., 2011 state: "The question of whether a particular forensic assay is accurate is far more important than that of uniqueness".

For acceptance in court, therefore, the origin or source of a piece of precious metal or precious metal-bearing material must be able to be shown as being the only probable one i.e. does the precious metal come from the alleged source or from elsewhere, and has this precious metal been illegally processed or not. The return of recovered stolen material would go to the most probable owner (balance of probability). There is a wide range of materials, which consist of or contain precious metal, both natural and manufactured. Thus the information required must be as comprehensive and inclusive as possible in order for a sound conclusion to be made on the basis of expert and informed scientific judgment (Stoney, 1991).

The use of a database for such purposes can enable the elimination of sources, but unless the number of potential sources is limited and known, it is not possible to make a categorical identification (Broeders, 2003). Due to the nature of precious metal deposits and manufacturing processes, however, it should be possible in many cases to constrain the number of potential sources and thus arrive at a most probable or only probable source, meeting the legal requirements.

Most publications on elemental fingerprinting of precious metals concern gold and silver, whether in the form of wrought goods such as coins (Ponting et al., 2003; Guerra 2005) and artefacts (Kovacs et al 2009), or as alluvial nuggets in order to trace the mineralised horizon. Fingerprinting has been practiced on gold (Watling et al., 1994) as well as the platinum group metals and also on precious stones, including diamonds (Coney et al., 2012). The investigation of the intermediate products of gold processing has been done by Nixon et al., 2011, to determine the origin of gold used to produce coins from debris in the moulds, and also Dixon 2014 and Roberts et al., 2016 in tracing the origin of illegally mined gold from the Witwatersrand Basin, South Africa.

A minor amount of research has been done on the fingerprinting natural platinum group minerals (e.g. Merkle and Franklyn, 1999) but little had been done on looking at the intermediate products of the production of platinum group metals until the problem of theft reached alarming proportions (UNICRI Report 2016). The major problems were identified in Russia, which was due mainly to the theft of material from their precious metal refineries (Perelygin et al., 2008) and in South Africa (Gastrow, 2001).

The identification of recovered mine and plant products is not a new concept and has been put in practice by several mining houses (Perelygin et al., 2008; CIP Project report, 2008; UNICRI Report, 2016). An upsurge in the platinum group metal prices from the mid 1990's onwards resulted in an increase in the theft of platinum refinery and smelter products, with two of the major producers, Anglo American Platinum and Norilsk Nickel, started applying standard processes in a systematic manner to routinely identify recovered platinum products. This resulted in Norilsk Nickel, in collaboration with the Institute of Criminalistics of the Federal Security Service (ICFSS) of the Russian Federation, approaching the European Network of Forensic Science Institutes to validate their methodology from an analytical and forensic perspective. A review board consisting of an international team of forensic scientists and specialist consultants exhaustively examined the methodology and recommended that development of the identification process be continued and that what had been presented "could be regarded as a starting point for development of methods by which consistent, comparable data can be obtained across the various producers", and which could be used internationally as standard methodology for presenting forensic findings in court (ENFSI, 2008).

The identification process uses a systematic approach, commencing with chemistry to determine the main producing area, after which more detailed mineralogical techniques are used in an attempt to further identify the specific product and pinpoint the producer. Variations in processing between different producers in the same mining area result 
in small differences in the products' textures and compositions, which can be picked up with specialised techniques. These techniques include a combination of X-ray diffraction, automated scanning electron microscopy and electron microscopy. The identification techniques are very similar, varying depending on the differences in grade between primary platinum producers (such as the Bushveld producers) and those that have platinum group metals as a by-product (i.e. Norilsk Nickel) and the differences in the precious metal extraction processes.

\section{Gold}

Native gold is a mineral composed mainly of $\mathrm{Au}, \mathrm{Ag}, \mathrm{Cu}$ and $\mathrm{Hg}$ in solid solution and it usually contains one or more trace metals as lattice impurities, as mineral inclusions, in grain boundaries or in surface coatings. Alloy proportions of the major and minor constituents, together with the suite of trace elements, can be thought of as constituting a gold profile. Gold is associated with a great variety of ore deposits and each has a characteristic profile. Different deposits within the same mineralised terrane can also have profiles which are similar, but distinct from each other.

LA-ICP-MS analysis of native gold shows that measurable amounts of many elements are present at detectable and highly variable levels in gold from different styles of lode mineralisation. This provides a wide range of elements to use as a geochemical fingerprint for gold. To date, very little LA-ICP-MS compositional data is available for gold with which to compare illicit material. This methodology has been used in some cases in the exploration for gold deposits by analysing placer gold to determine type and number of deposits reflected by the suite of sources identified, e.g. Outridge et al., 1998 and Mortensen et al., 2005.

In South Africa it has been challenging to successfully implement gold profiling. South Africa has a large number of gold mines, a wide range of genetically distinct gold deposits in discrete geological environments (Department of Minerals and Energy, 2006; Robb and Robb, 1998; Ward and Wilson, 1998), and is also the final refining destination for quantities of gold from all over Africa and South America. Furthermore, most of the South African gold mines exploit gold hosted in Archaean alluvial fans of the Witwatersrand Basin (Goldfarb et al., 2001; Hallbauer and Barton, 1987; Frimmel, 1997). Detrital gold in different fans reflects the whole hinterland with different geological characteristics in the source areas. Although gold in each fan is a mixture of original deposits in the source areas, differences can still be expected.

Thus most mines in South Africa are situated on geologically similar deposits, and there is often more than one mine on a particular deposit. Furthermore, a large amount of gold theft in South Africa does not occur from the processing plants, but actually from the ore face itself. Raw ore is processed by primitive means such as amalgamation, and then sold on to large organised syndicates, who customarily mix gold from several localities and types together. This means that a wider range of gold products and compositions are commonly seized by the police in South Africa, necessitating a more complex approach to the forensic identification of the source of such gold.

Under South African law, it is not legal to process gold or possess gold, which has not been refined to over $99.9 \%$ purity and has not undergone any manufacturing process, without a permit (Precious Metals Act, 2005). The use of elemental profiling to distinguish between legal gold alloys and illegally processed gold, which represents gold stolen from mining operations, provides a legal mechanism for the seizure of such material. Elemental analysis of seized gold is sufficient to discriminate between the various methods by which the metallic gold has been produced. The amount of illicit gold seized is substantial, and no legal producer employs either lead or mercury collection for gold production, so the mere identification of the process used will identify whether the method used was employed by a legal producer or not. In some situations a licensed plant will process material from a different source than that stated on its invoices. In this case the profile can be compared to the profiles in the database, and material sourced from the stated origin. This situation arises when a mine is purchased in order for it to act as a conduit through which stolen material can be laundered.

\section{Case Examples}

Holders of a recovery licence are legally entitled to buy gold-bearing material from persons who are legally entitled to possess it, in order to recover the precious metals from the material. Changes to South African legislation have made it easier for people to acquire such licences, and the effect of elevated precious metal prices over the past few years, have combined to produce an environment in which there are more persons wanting to buy gold-bearing material for re-processing than there are suppliers, resulting in a thriving trade in illicit dealing.

A lot of gold submitted for refining comes from jewellers, pawn brokers and recovery license holders, and is stated to be either scrap jewellery or of industrial gold alloy origin, recovered during recycling of electrical circuits, dental alloys, etc. In South Africa most jewellery sold and pawned is of low caratage, between 8 and 14 carats, whereas most of the material purported to be jewellery scrap is around 16 to 18 carats. It would be expected that this gold would have a relatively limited range of elements present, and little in the way of trace elements, as the original materials would have been alloyed from pure metals. However, the majority of this material is highly variable in composition.

Jewellery alloys and manufactured jewellery consist primarily of $\mathrm{Au}, \mathrm{Cu}, \mathrm{Ag}, \mathrm{Pd}$ and $\mathrm{Zn}$, with some older jewellery containing small amounts of $\mathrm{Rh}$, added when the metal was relatively cheap. Besides the presence of some unusual combinations of elements in the alloys obtained from Rand Refineries, there is very little variability in the trace element content of jewellery gold. Unrefined mine bullion from the mines in South Africa contains significant amounts of Ag, but very little $\mathrm{Cu}$. Trace elements such as $\mathrm{Ni}, \mathrm{Pb}, \mathrm{Sn}, \mathrm{In}, \mathrm{Pt}, \mathrm{Mn}$ and Ti can be present in the profile, as well as elements such as As and Te. The concentration of these elements is exceedingly variable, but can be in the order of 1 or $2 \mathrm{wt} \%$ of the sample. A distinctive characteristic of unrefined gold from the Witwatersrand Basin is the anomalous $\mathrm{Pb}$ isotope profile. The elemental compositions and $\mathrm{Pb}$ isotope profiles are usually sufficient evidence to get a conviction (Figure 2).

The dealers buy stolen gold, which is normally between $85-95 \%$ $\mathrm{Au}$, often add diluent material to this gold, to produce gold which has a caratage, which would be expected if the material smelted was of jewellery origin. The diluents used are often copper wire, brazing rods, 


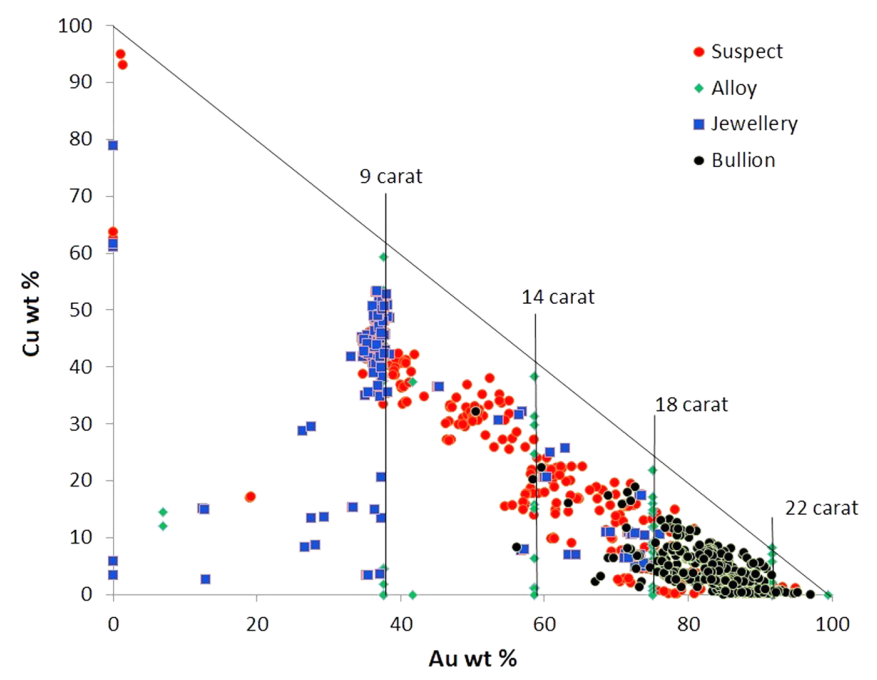

Figure 2. Comparison between seized gold (suspect: in red) and gold from known sources (alloys, jewellery, and bullion), based on Au and $\mathrm{Cu}$ content. The commercially produced alloys (in green) show the groupings according to carat value. Pieces of brass and copper, and Au-free jewellery (possibly Au-coated jewellery with a negligible Au content), are shown against the y axis. It can be seen that the suspect samples have much greater variation than the normal jewellery (Roberts et al., 2016).

or coins. These are used because they do not change the colour of the gold produced. However, whether pure copper, or a copper alloy is used to dilute the stolen gold, it is very easy to identify the diluent and subtract that from the bulk composition, and hopefully identify the origin of this stolen mine gold. It has also been possible, in a number of cases, to link gold from different seizures to the same smelt house based on the specific composition of the diluent material (Figure 3).

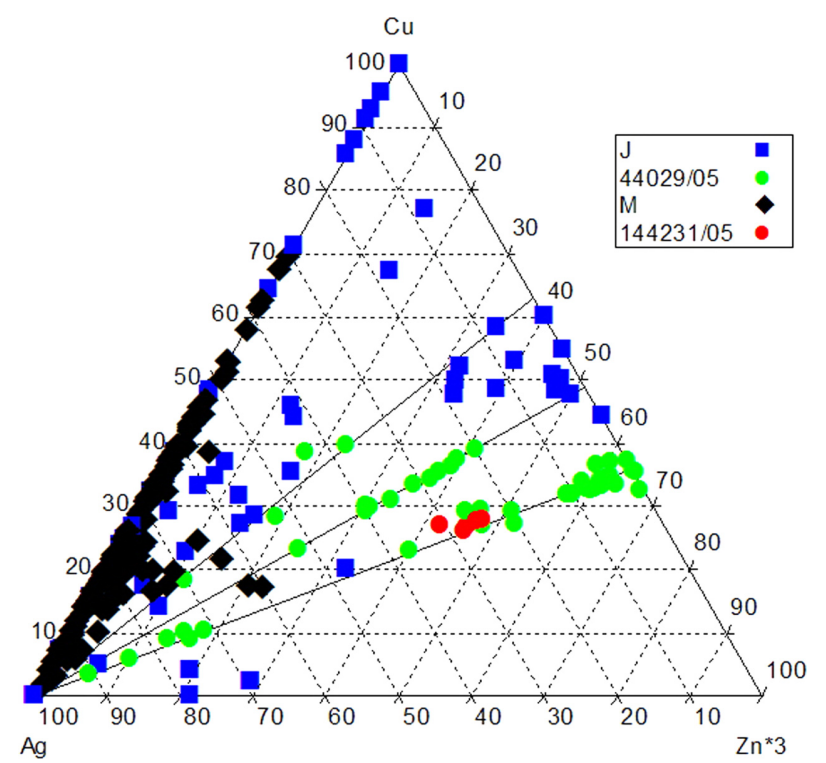

Figure 3. Mixing lines showing the composition of 3 different types of brazing rods, mainly alloys of Cu:Zn in specific ratios, which have been added to stolen mine gold in two different cases (green and red dots). The blue squares are jewellery compositions, and the black diamonds mine gold. The jewellery and mine gold compositions are from the South African gold database.

\section{Platinum Group Metals}

The theft of platinum group metal (PGM) bearing materials from smelters and refineries in the country of origin is an ongoing problem worldwide. The stolen materials are generally refined in countries far from source and usually without local sources of raw materials. In order to stem the illicit trade in these stolen materials, fingerprinting of recovered mine and plant products has been implemented (Perelygin et al., 2008; ENFSI, 2008) with the aim of returning recovered material to their legal owners, and enabling successful prosecution in court.

Although chemical data can be used to discriminate between the world's PGM deposits, these deposits are commonly exploited by a number of mining companies. With different mining companies mining in the same mining area and in many cases the same reef types the resulting overlaps in chemical and mineralogical characteristics make it difficult to determine the exact provenance. For example, different producers operating on the Bushveld Complex in South Africa mine both the Merensky and UG-2 reefs. Although the two reef types have very different chemical and mineralogical characteristics, the feed to the process is commonly a blend of these two ore types. This makes it impossible to link a recovered process product to a specific producer based on ore type characteristics. Although it might also be possible to trace back the origin of recovered material from a specific point in the beneficiation process, this requires a database of the characteristics (chemical and mineralogical) of all products originating from the various operations.

In South Africa, smelter products are most at risk of being stolen, although lately the feed to the smelters (lower grade concentrates) are also being targeted by syndicates. The most abundant at-risk valuable material in South Africa is converter matte, which is stolen from the smelting operations, or when in transit between smelting operations and refineries. Converter matte is a product within the beneficiation process that still retains most of the chemical characteristics of the ore types treated (e.g., Pt to Pd ratios, $\mathrm{Cu}$ and $\mathrm{Ni}$ contents). It also has the advantage that the product acquires additional differentiating characteristics imposed by the specific pyrometallurgical route with converter matte forming the feed to the subsequent hydrometallurgical process. For example some producers granulate their converter matte while other slow-cool their product for subsequent processing.

Stolen material is often mixed in an attempt to mask the origin and thus legitimacy of the material submitted to a refiner for processing. In these cases it is often also possible to identify the sources of individual grains in these mixtures of converter mattes from different producers using textural and compositional analyses. A combination of physical properties (e.g., shape, size, density), chemistry and mineralogy is used to determine the fingerprint of the main producing areas, the specific product and the producer. The techniques used include Xray diffraction and automated scanning electron microscopy.

A comparison of converter mattes from various producers across the platinum-producing provinces highlighted some very important differences between the products. Producers investigated included primary platinum group metal producers such as the Bushveld and Great Dyke operations in South Africa and Zimbabwe respectively, as well as those producers that manufacture platinum group metals as a by- 
product from base metal operations (operations in Russia, Canada, and Botswana).

The most characteristic features of converter mattes which have enable restitution of stolen material, as well as successful prosecution, include:

- Converter mattes from primary PGE-producers are characterised by much higher PGE concentrations.

- Converter mattes from primary southern African PGE-producers exhibit Pt to Pd ratios in excess of 1.0.

- In pure form, some macro-physical characteristics (granulated vs. crushed and particle size distributions) can be used to further differentiate between mattes from some of the southern Africa primary PGE-producers.

- Major and trace element data might aid in identification and differentiation, but chemistry on its own will not be conclusive.

- Different mattes, although having similar compositions and therefore containing similar phases, exhibit different textural characteristics. These differences are mainly manifested by the distribution, grain sizes and shape of the alloy phases.

- Specific phases present in converter mattes, such as alloy and spinel, have different compositions, and can be used to further differentiate between mattes from various producers.

Although some of the distinguishing characteristics identified will persist in subsequent processing, one needs to use a combination of chemical and mineralogical techniques, as well as have a thorough understanding of the various processes, to identify the product as well as the producer (Figure 4 and Figure 5).

This approach has resulted in successful prosecutions, including action against refineries shown to have knowingly accepted stolen material from other countries. The methodology applied, as well as providing guidelines to its successful implementation in combatting the cross border illicit PGM trade (Figure 6).

\section{Case Examples}

The fingerprinting of platinum group metal containing products has been applied in several court cases.

In 2009, a European Refining Company contacted the South African Police in connection with a consignment of dubious source which they expected to be of South African origin. After detailed characterisation the material was identified as products from two South African producers. The value of the consignment was calculated as US $\$ 815,977$. Based on the fingerprinting and other evidence the court ruled in favour of SA's allegations that the material originated from SA.

Also in 2009, and with the assistance of a European refining company Norilsk Nickel provided evidence to the Criminal Court of Antwerp that the delivery of 2.8 tons of slimes to the refining company represented material stolen from the JSC Kola MMC. The trading company involved was charged under Article 505 (legalization and laundering of criminally-obtained property) of the Criminal Code of

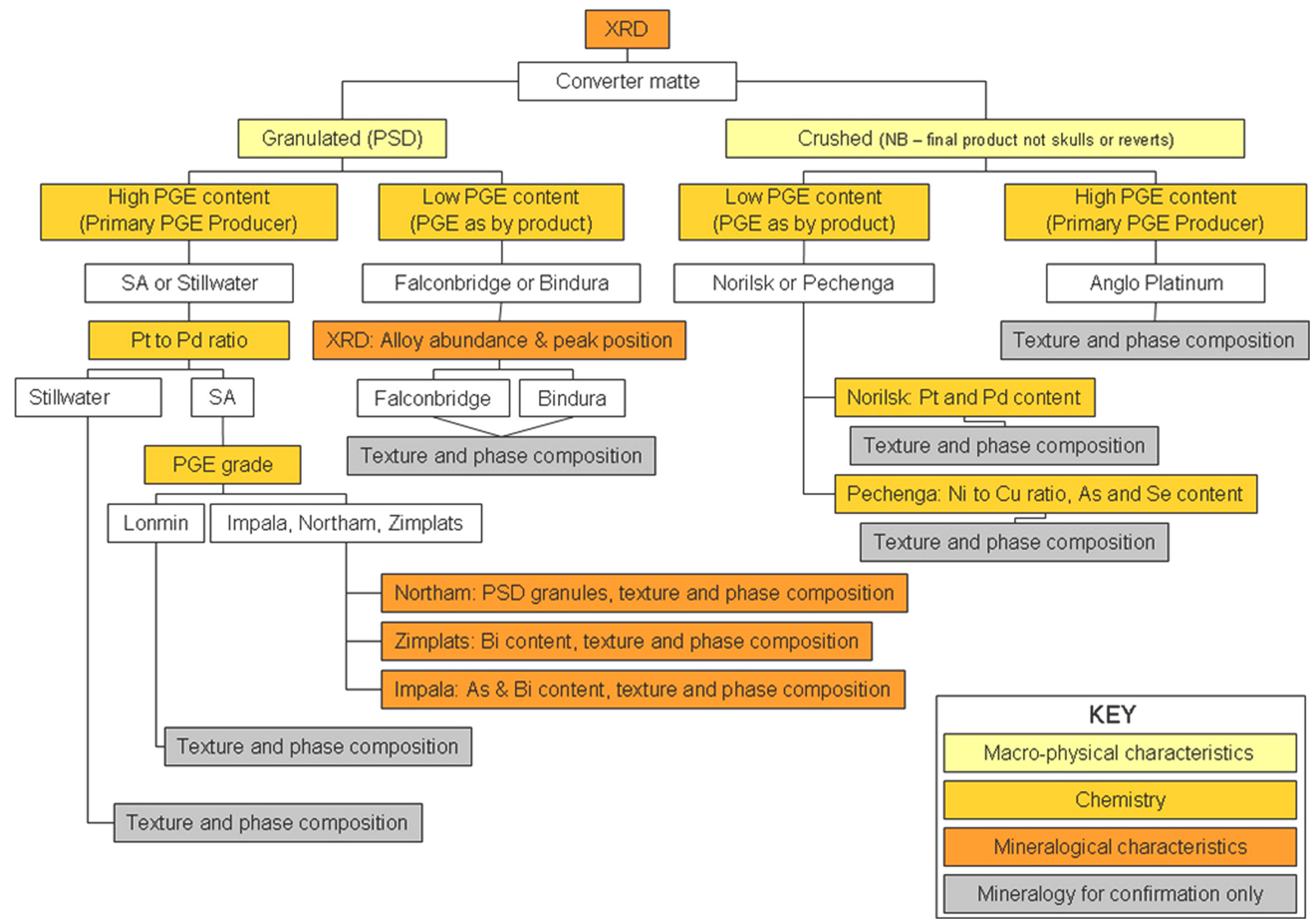

Figure 4. Diagram highlighting the information needed to identify converter mattes from various producers (ENFSI, 2008). 


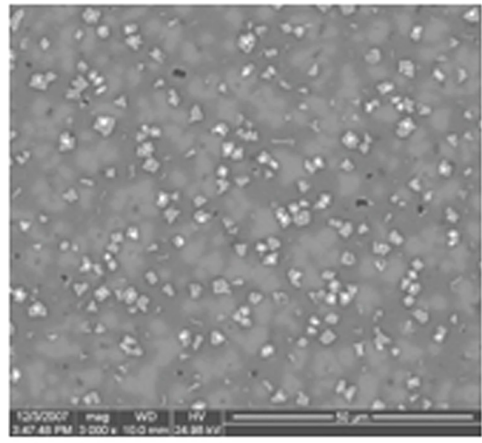

Impala Platinum

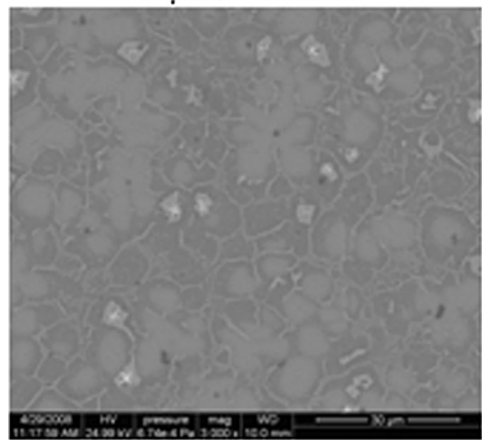

Northam Platinum (b)

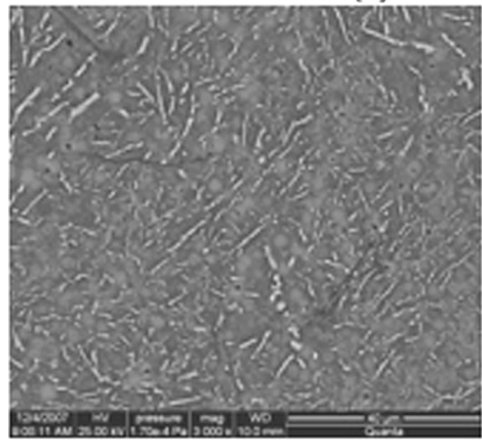

Falconbridge

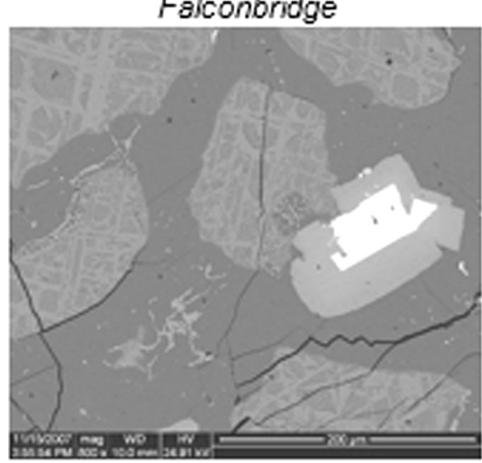

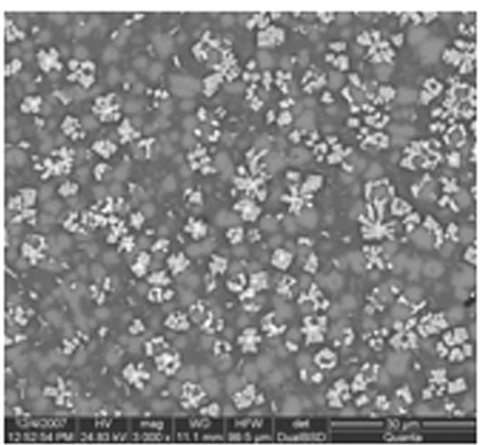

Lonmin Platinum

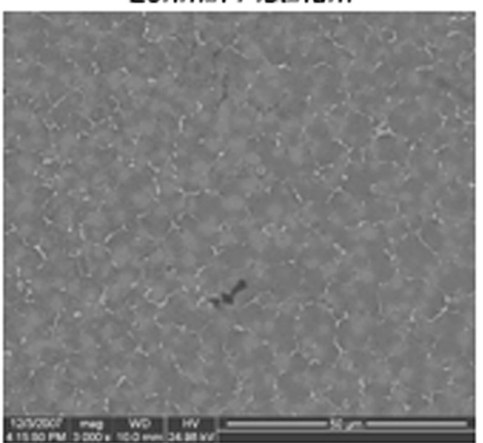

Zimplats
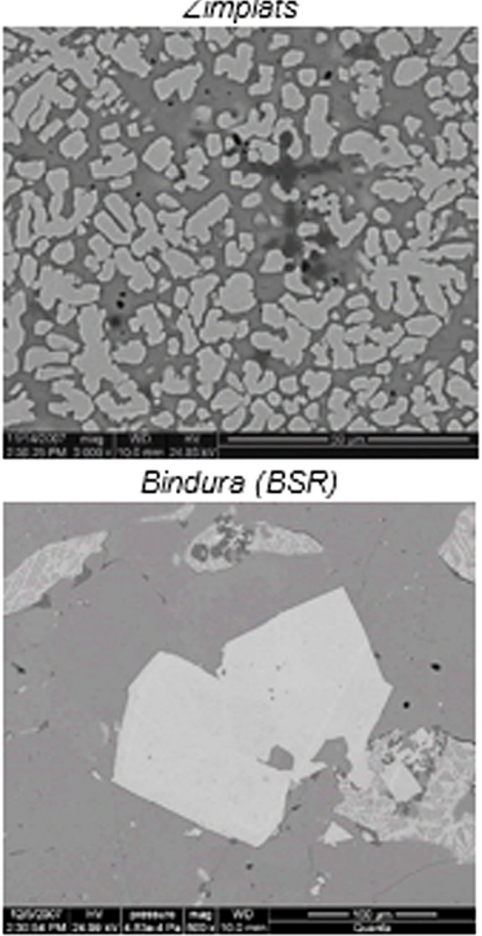
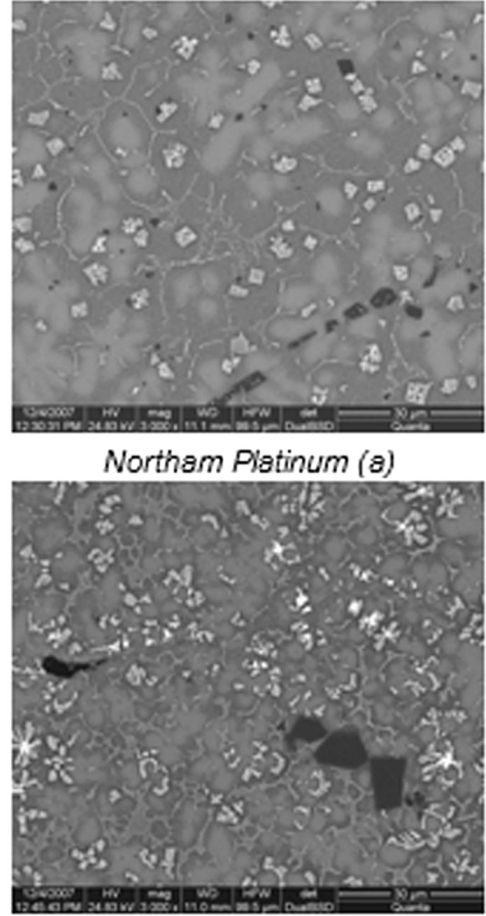

Stiowater

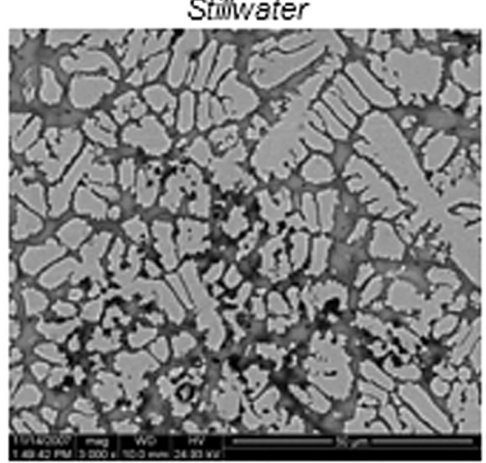

Bindura (BCL)

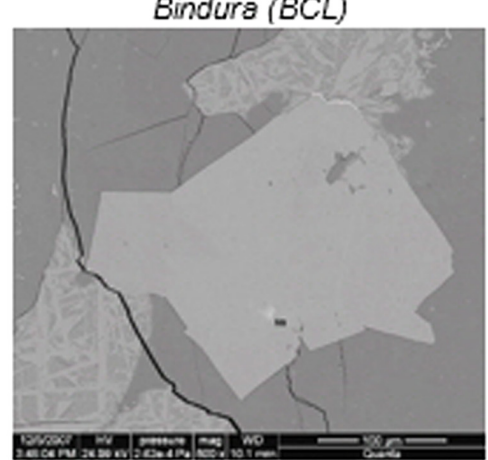

Figure 5. Backscattered electron images highlighting the differences in alloy shapes and alloy size distribution for various converter mattes. The brighter phases are alloy set in a darker sulphide matrix. Note that the alloy from different producers exhibit different shapes (square, starshaped or worm-like). White specks in the granulated converter mattes are PGE-rich alloys. The images of the Bindura matte highlight the abundance of alloy. The alloy in the slow-cooled converter mattes occur as larger plates. The white core to the base metal alloy phase in the slowcooled Anglo Platinum converter matte is Pt-rich. This is an example of the type of information that is required to differentiate between similar materials produced during the beneficiation of platinum group metals (ENFSI, 2008).

Belgium. Having examined the evidence collected the court found these sufficient to make a final decision and found the trading company guilty on the charge. The trading company was fined $€ 2,000$ and ordered to compensate Norilsk Nickel Group for legal costs in the amount of $€ 30,000$. The amount related to the value of the processed slimes (an amount of $€ 150,000$ ) was returned to Norilsk Nickel (UNICRI Report, 2016). 

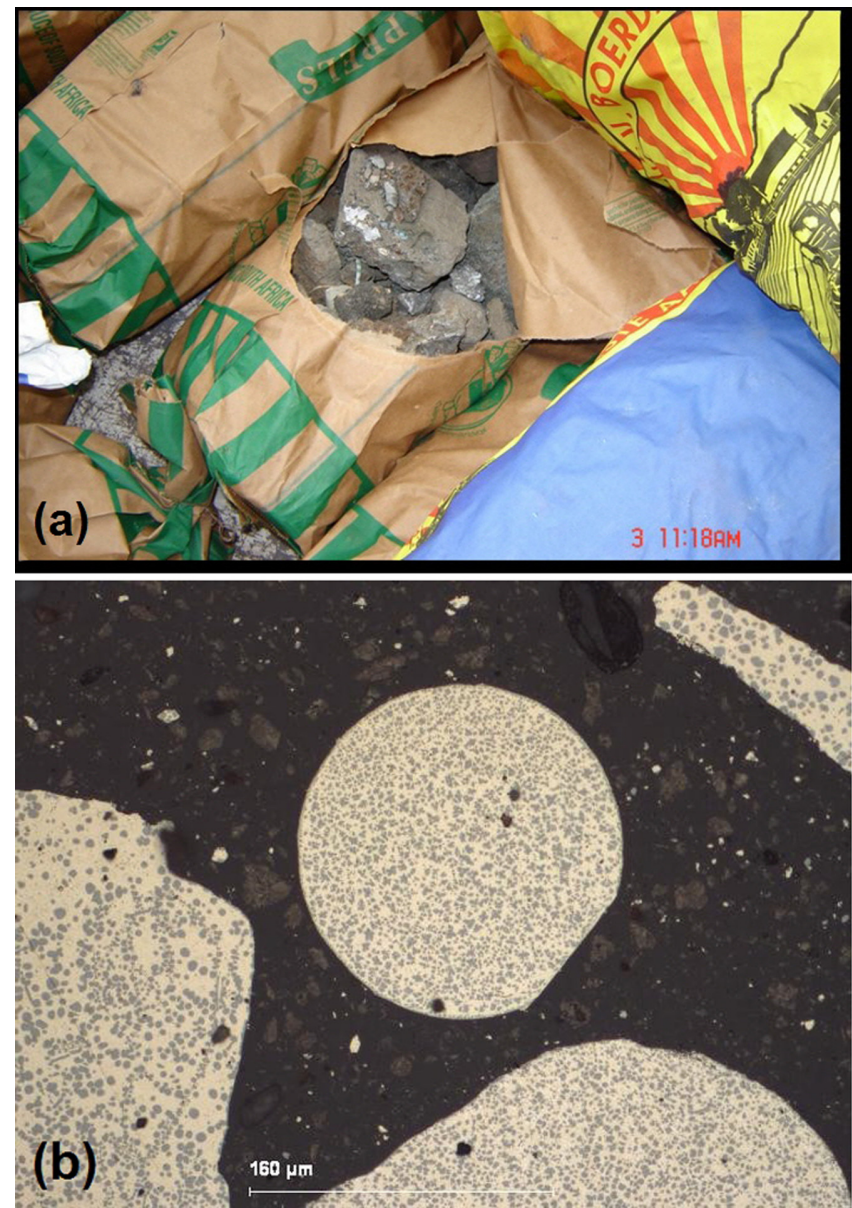

Figure 6. (a) A shipment of converter matte, packaged as potatoes, intercepted on the way out of South Africa en route to a refinery in Europe. (b) Polished section of matte from a South African platinum producer showing the typical texture of granulated converter matte (a distinguishing feature of some producers).

\section{Conclusion}

The illegal theft, trade and trafficking of precious metals is a major problem worldwide. The materials trafficked only become "legitimate" when they approach the final product, usually at a refinery far from the origin. The identification of the illicit material and its source is a complex task. The application of forensic fingerprinting techniques, which are employed in South Africa, the Russian Federation and Australia, rely on databases of products from various mines and areas, which are used for comparison purposes. In order to increase the effectiveness and applicability of the techniques, and expand its use to other countries, there has to be greater cooperation between authorities and investigators, and gold and platinum-group element databases will need to be expanded. In all of this, the specialist forensic geologist is crucial in taking the investigation from analysis to court.

\section{References}

Andean Air Mail and Peruvian Times, 2012, Peru's illegal gold mining bigger than drug trade: Andean Air Mail and Peruvian Times, May
17, 2012. http://www.peruviantimes.com/17/perus-illegal-gold-mining-bigger-than-drug-trade/15746/.

Bariyo, N., Freeman, F., and Pleven, L., 2013, Wie Blutgold aus dem Kongo auf den Weltmarkt gelangt: The Wall Street Journal, 15 April. Available at http://www.wallstreetjournal.de/article/SB1000 1424127887324485004578424543527900854.html [accessed May 1, 2013].

Broeders, A.P.A., 2003, Forensic evidence and international courts and tribunals - Why bother, given the present state of play in forensics? $17^{\text {th }}$ Conference of the International Society for the Reform of Criminal Law, The Hague, Netherlands, August 24-28.

BSR, 2010, Conflict minerals and the Democratic Republic of Congo: Retrieved from www.BSR.org

Coetzee, B., and Horn, R., 2007, Theft of precious metals from South African mines and refineries: ISS Monograph Series, no. 133, p. 122.

Coney, L., Moila, A.V., and Quadling, A.G., 2012, Gem-quality diamonds: source discrimination: South African Journal of Geology, v. 115, no. 1, pp. 33-46.

de la Rey, J.H., 2007, The fact-finding process and the burden of proof during litigation: Legum Magister thesis, University of Pretoria, Pretoria, South Africa.

Department of Minerals and Energy, 2006, South Africa's Mineral Industry 2005/2006 (23 $3^{\text {rd }}$ edition): Pretoria, 173 p.

Dixon, R.D., 2014, Provenance of illicit gold with emphasis on the Witwatersrand basin: Ph.D. thesis, University of Pretoria, Pretoria, South Africa.

Dodd-Frank Wall Street Reform and Consumer Protection Act, 2010, Dodd-Frank Section 1502: $111^{\text {th }}$ Congress Public Law 203.

Donovan, D.R., 2014, Mineral smuggling in Central Africa: Africa Conflict Monthly Monitor, pp. 62-66.

ENFSI, 2008, CIP Project: Report of the CIP Forensic Review Board, European Network of Forensic Science Institutions, The Hague, The Netherlands, Accessed at http://www.enfsi.eu/documents/cip-projectreport.

Farah, D., 2002, Al Qaeda's road paved with gold: secret shipments traced through a Lax system in United Arab Emirates: Washington Post Foreign Service, February 17, 2002, pp. A01.

Frimmel, H.E., 1997, Detrital origin of hydrothermal Witwatersrand gold - a review: Terra Nova, v. 9, no. 4, pp. 192-197.

Gäbler, H.E., Melcher, F., Graupner, T., Bahr, A., Sitnikova, M.A., HenjesKunst, F., Oberthür, T., Brätz, H., and Gerdes, A., 2011, Speeding up the analytical workflow for Coltan Fingerprinting by an integrated mineral liberation analysis/LA-ICP-MS approach: Geostandards and Geoanalytical Research, v. 35, no. 4, pp. 431-448.

Gastrow, P., 2001, Theft from South-African mines and refineries: B. The illicit market for gold and platinum: ISS Monograph Series, no. 54, 72 p.

George, M.W., 2007, Gold: U.S. Geological Survey, Mineral Commodity Summaries, U.S. Department of the Interior.

Goldfarb, R.J., Groves, D.I., and Gardoll, S., 2001, Orogenic gold and geologic time: a global synthesis: Ore Geology Reviews, v. 18, no. 1-2, pp. $1-75$.

Guerra, M.F., 2005, Trace elements fingerprinting using accelerators and ICP-MS: circulation of gold from the $6^{\text {th }}$ century $\mathrm{BC}$ to the $12^{\text {th }}$ century AD. in Van Grieken, R., and Janssens, K. (eds.), Cultural heritage conservation and environmental impact assessment by non-destructive testing and micro-analysis: Taylor and Francis, London.

Haken, J., 2011, Transnational crime in the developing world: Global Financial Integrity, Center for International Policy, Washington, $57 \mathrm{p}$.

Hallbauer, D.K., and Barton, J.M., 1987, The fossil gold placers of the Witwatersrand: Gold Bulletin, v. 20, pp. 68-79.

Inman, K., and Rudin, N., 2002, The origin of evidence: Forensic Science International, v. 126, pp. 11-16.

Kovacs, R., Schlosser, S, Staub, S.P., Schmiderer, A., Pernicka, E., and Gunther, D., 2009, Characterization of calibration materials for trace element analysis and fingerprint studies of gold using LA-ICP-MS: 
Journal of Analytical Atomic Spectrometry, v. 24, pp. 476-483.

Lublinski, J., Griebeler, M., and Farivar, C., 2010, Coltan mines to be 'fingerprinted', German scientists say: Retrieved from http:/www.dw.de/ coltan-mines-to-be-fingerprinted-german-scientists-say/a-5907446 on 2013-06-11

Merkle, R.K.W., and Franklyn, C.B., 1999, Milli-PIXE determination of trace elements in osmium-rich platinum-group minerals from the Witwatersrand basin, South Africa: Nuclear Instruments and Methods in Physics Research B, v. 158, pp. 556-561.

Mortensen, J.K., Chapman, R., LeBarge, W., and Jackson, L., 2005, Application of placer and lode gold geochemistry to gold exploration in western Yukon, in Emond, D.S., Lewis, L.L., and Bradshaw, G.D., eds, Yukon Exploration and Geology 2004, Yukon Geological Survey, pp. 205-212.

Nixon, S., Rehren, T., and Guerra, M.F., 2011, New light on the early Islamic West African gold trade: coin moulds from Tadmekka, Mali: Antiquity, v. 85, pt. 330, pp. 1353-1368.

Outridge, P.M., Doherty, W., and Gregoire, D.C., 1998, Determination of trace elemental signatures in placer gold by laser-ablation inductivelycoupled plasma-mass spectrometry as a potential aid for gold exploration: Journal of Geochemical Exploration, v. 60, pp. 229-240.

Page, M., Taylor, J., and Blenkin, M., 2011, Uniqueness in the forensic identification sciences - fact or fiction?: Forensic Science International, v. 206, pp. 12-18.

Perelygin, A., Kuchkin, A., Kharkov, N., and Moskvina, T., 2008, Criminalistic identification of PGM-containing products of mining and metallurgical companies: Forensic Science International, v. 174, pp. $12-15$.

Ponting, M., Evans, J.A., and Pashley, V., 2003, Fingerprinting of Roman mints using laser-ablation MC-ICP-MS lead isotope analysis: Archaeometry, v. 45, pp. 591-597.

Precious Metals Act, 2005, Act 37 of 2005: Government Gazette, v. 28764, pp. 2-28. 21 April, 2005.

Rand Refinery, 2012, Integrated annual report 2012: Johannesburg.

Robb, L.J., and Robb, V.M., 1998, Gold in the Witwatersrand Basin. in Wilson, M.G.C., and Anhaeusser, C.R. (eds.), The mineral resources of South Africa: Council for Geoscience, Handbook 16, pp. 294-349.

Roberts, R.J., Dixon, R.D., and Merkle, R.K.W., 2016, Distinguishing between legally and illegally produced gold in South Africa: Journal of Forensic Science, v. 61, pt. S1, pp. S230-S235.

S v. Abrahams, 1979, 1979 (1) SA 203 (A).

S v. Janse van Rensburg and Another (A 689/2007), 2008, ZAWCHC 40; 2009 (2) SACR 216 (C) (24 July 2008).

Saks, M.J., and Koehler, J.J., 2005, The coming paradigm shift in forensic identification science: Science, v. 309, pp. 892-895.

Savu-Krohn, C., Rantitsch, G., Auer, P., Melcher, F., and Graupner, T., 2011, Geochemical fingerprinting of Coltan ores by machine learning on uneven datasets: Natural Resources Research, v. 20, pp. 177-191.

Schmidt, C.W.H., and Rademeyer, H., 2006, Bewysreg, Butterworths, Durban.

Smith, T., 2008, Materials profiling: identification of source within a legal context: Unpublished thesis, University of Pretoria, Pretoria, Argentina.

Stoddard, E., 2013, South Africa mining to shed jobs in troubled times: Reuters, Cape Town, Wed Feb 6, 2013 12:24 pm EST, Retrieved from http://www.reuters.com/article/2013/02/06/us-africa-mining-jobs-idUSBRE9150Z820130206.
Stoney, D.A., 1991, What made us ever think we could individualize using statistics?: Journal of the Forensic Science Society, v. 31, pp. 197-199.

United Nations, 2000, Kimberley process certification scheme: United Nations General Assembly Resolution, 55/56.

UNICRI, 2016, Strengthening the security and integrity of the precious metals supply chain: United Nations Interregional Crime and Justice Research Institute Technical Report, $122 \mathrm{p}$.

Ward, J.H.W., and Wilson, M.G.C., 1998, Gold outside the Witwatersrand basin. in Wilson, M.G.C., and Anhaeusser, C.R. (eds.), The mineral resources of South Africa: Council for Geosciences, pp. 350-386.

Watling, R.J., Herbert, H.K., Delev, D., and Abell, I.D., 1994, Gold fingerprinting by laser ablation inductively coupled plasma mass spectrometry, Spectrochimica Acta Part B: Atomic Spectroscopy, v. 49, pp. 205-219.

Watling, R.J., Scadding, C.J., and Dixon, R.D., 2010, Chapter 88A : Gold - identifying its provenance. in Freckelton, I., and Selby, H. (eds.), Expert evidence: Thomson Reuters, Australia.

White, D., 2005, Curse of Africa's precious metal haunts miners: Financial Times, $1^{\text {st }}$ June 2005.

World Gold Council, 2011, World gold council standard: Conflict-Free Gold, 16 June 2011, version 5.3., 40 p.

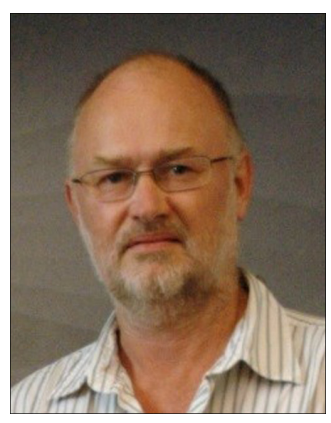

Roger Dixon has an MSc (Geology, from the University of Cape Town, and a PhD (Geology) from the University of Pretoria. In 1982, he worked for the Geological Survey of South Africa as a mineralogist. He then joined the Forensic Science Laboratory of the South African Police Service in 1994. Establishing Forensic Geology as an essential disciple, he ran the Materials Analysis Section, he was responsible for the establishment of the precious metal fingerprinting laboratory and database, in conjunction with mining companies. At the Department of Geology, University of Pretoria, he runs the Stoneman Laboratory. Roger is the IUGSIFG Officer for Africa.

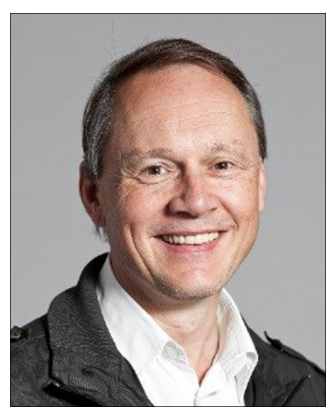

Robert Schouwstra has an MSc (Geology) from the University of Johannesburg, a Masters in Minerals Resource Management from the University of the Free State and a DSc (Geology) from the North-West University. An experienced process mineralogist, he is an expert in the fingerprinting of precious metal containing products. An advisor to the Forensic Peer Review Board (ENFSI) on the identification of these materials, he has assisted the Belgian State Prosecutor, the Attorney General of Switzerland and the South African Police Service with investigations. He is assisting UNICRI with the requirements for an international strategy to combat illicit trafficking in precious metals. 